\title{
アトピー性脊髄炎による運動障害に対するリハビリテーション
}

\author{
吉田直樹*1,2 福岡哲男*1 今西幸仁 $* 1$ \\ 藤井良憲*1向野雅彦*2 大田哲生*2
}

\section{The Rehabilitation of a Patient with Several Symptoms Associated with Atopic Myelitis}

\author{
Naoki Yoshida, ${ }^{* 1,2}$ Tetsuo Fukuoka, ${ }^{* 1}$ Yukihito Imanishi, ${ }^{* 1}$ \\ Yoshinori FujII, ${ }^{* 1}$ Masahiko MukaIno, ${ }^{* 2}$ Tetsuo OTA ${ }^{* 2}$
}

\begin{abstract}
We report a patient displaying several symptoms of myelitis associated with atopic dermatitis. The patient, a 35-year-old female, initially suffered from gait titubation that gradually developed into motor disturbance. She underwent many tests (blood, cerebrospinal fluid, electromyography, and brain, cervical, and lumbar spinal cord and muscle MRIs) at several hospitals, including a university institution, over the course of two years until she finally came to our hospital. However, her disease was never identified by these tests, and she was referred to our hospital to start rehabilitation for her disability which was believed to be caused by disuse syndrome. On first examination, muscle hypertonia of both legs, hypoesthesia of all extremities, difficulty sitting, and a low performance level of ADL were observed. Judging by the factors (e.g. age, neurological symptoms), we considered that the patient was not suffering disuse syndrome, and recommended that she attend another medical college hospital for a thorough investigation. The disease was finally diagnosed as atopic myelitis, as indicated by the test results (e.g. hyperIgEemia). She could sit without a back rest and undertake gait training between parallel bars after steroid pulse therapy at the hospital. While she undertook rehabilitation at our hospital, we applied some approaches to adapt to her fluctuating symptoms (e.g. making short leg braces for both legs, injection of botulinum toxin A $\left(\right.$ BOTOX $\left.^{\circledR}\right)$ in the leg). We recognized we should gather as much information as possible given the rarity of the disease. (Jpn J Rehabil Med 2013; $50: 339-344$ )
\end{abstract}

Key words : アトピー性脊髄炎（atopic myelitis）, 廃用症候群（disuse syndrome）, 高 $\operatorname{IgE}$ 血 症 (hyperIgEemia)

\section{はじめに}

アトピー性皮膚炎は，増悪・寛解を繰り返す，掻痒 のある湿疹を主病変とする疾患であり，患者の多くは アトピー素因を持つ。病態は表皮・なかでも角層の異 常に起因する皮虐の乾燥とバリアー機能異常という皮 膚の生理学的異常を伴い, 多彩な非特異的刺激反応お よび特異的アレルギー反応が関与して生じる ${ }^{11}$ 。アレ
ルギー性疾患に伴う神経障害として, Churg-Strauss 症候群（アレルギー性肉芽腫性血管炎）がよく知られ ている，本症では，免疫応答を基調とした過敏反応に よる血管炎と共に高率に末梢神経障害を生じる2,3). 中枢神経障害に関しては，稀に脳出血や脳梗塞の報告 はあるが，脊髄炎を発症したとの報告はない。中枢神 経障害とアレルギー性疾患の関連性を示したこれまで の報告は，小児期の Hopkins 症候群を除いてほとん

2012 年 10 月 2 日受付, 2013 年 4 月 18 日受理

*1 医療法人吉栄会 吉川病院/ $=596-0813$ 大阪府岸和田市池尻町 98 番地

Yoshieikai Yoshikawa Hospital

*2 旭川医科大学病院リハビリテーション科/テ 078-8510 北海道旭川市緑が丘東 2 条 1 丁目 1 番 1 号

Department of Physical Medicine \& Rehabilitation, Asahikawa Medical University Hospital

E-mail : nyoshida@asahikawa-med.ac.jp 
ど認められない。この症候群は喘息発作後 2 週間以内 に発症する急性脊䯣炎により弛緩性麻痺を呈する疾患 である ${ }^{3 \sim 5)}$. 1997 年に Kira らは成人のアトピー性皮膚 炎患者で頸䯣炎がみられることを報告した ${ }^{6}$ 。これら の症例では頸髄に病巣を有し，一旦発症すると慢性動 摇性の臨床経過をたどり脊髄 MRI（magnetic resonance imaging）上，異常を認めるなど特異な病像を 示している。また種々の中枢神経疾患患者で血清全 IgE（immunoglobulin E）およびアレルゲン特異的 $\mathrm{IgE}$ を測定し，ウイルス性など原因の明らかなものを 除いた脊髄炎の患者（アトピー性皮膚炎合併群を含 む）では，健常対照より有意に高 IgE 血症の頻度お よび血清ダニ抗原特異的 $\mathrm{IgE}$ 陽性率が高いことを明 らかにした ${ }^{7)}$ 。そこでKira らはその機序に関して，ア トピーを基盤として脊䯣に炎症を生じる病態と考え， アトピー性脊髄炎（atopic myelitis：AM）との病名を 提唱している ${ }^{6,8,9)}$. 今回，この稀な疾患を経験したの で，リハビリテーション（以下，リハ）の経過も含め て報告する。

\section{症例}

35 歳, 女性.

現病歴: $\mathrm{X}$ 年 5 月頃より歩行時のふらつきが出現. 徐々に歩行や階段昇降などの運動障害が進行してきた ため, 近隣の総合病院，A大学病院（神経内科/整形 外科）で MRI（頭部・頸部・腰部等), 髄液検査, 針 筋電図を施行したが，特に異常を認めなかった。その 後，少しずつ症状は進行した。 $\mathrm{X}+1$ 年 10 月頃より下 肢筋痛があり，近隣の市立病院で血液検査上軽度 $\mathrm{RF}$ (Rheumatoid Factor) 值の上昇を認めたが，膠原病内 科の診断では膠原病は否定的であった。 その後，大学 病院に $\mathrm{X}+2$ 年に市立病院（神経内科）で再度，電気 生理学的検査 (針筋電図), HTLV-1 (Human T-Lymphotropic Virus type I ）検査等を施行したが，特に 異常を認めなかった。廃用症候群との診断で $X+2$ 年 9 月 22 日に当院紹介受診となった。受診時，両下肢 (腸腰筋，大腿四頭筋，前脛骨筋）は MMT（Manual Muscle Test）2で筋緊張（膝関節伸展，足関節背屈） は立進 (痤固縮), 触覚は両側上肢 $5 / 10$, 下肢 $2 / 10$ と低下．動作は起き上がりから介助が必要で，端座位 保持不可，日常生活動作（ADL）重介助の状態であっ た. 年齢, 神経症状より精査が必要と判断し，B大学 病院（神経内科）に紹介し精査加療のため入院となっ

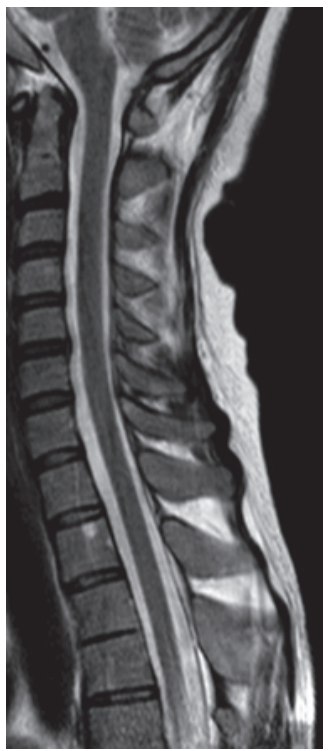

図 1 再精査目的入院時の頸部 MRI 明らかな異常所見を認めず.

た。頸部 MRI 画像では明らかな異常所見はないが（図 1)，著明な血中 $\mathrm{IgE}$ 值の上昇と中枢運動伝導速度の 低下を認め，アトピー性脊髄炎と診断された。ステロ イドパルス療法と血漿交換療法を行い，さらにB大 学病院入院中のリハによって，端座位可能，平行棒内 歩行練習レベルまで回復した。B 大学病院入院中に一 時的に尿閉となり尿道カテーテル留置となったが次第 に尿閉症状が軽減したため抜去となった． X+2 年 12 月 6 日にリ八目的で当院に入院となった.

\section{前医検查所見}

1）血液検查所見：IgE-RIST（Radio ImmunoSorbent Test） $3170 \mathrm{IU} / \mathrm{ml}$ ，好酸球 15\%，その他の明ら かな異常所見なし.

2）中枢運動伝導速度：右 $19.9 \mathrm{~m} / \mathrm{s}$ ，左 $21.2 \mathrm{~m} / \mathrm{s}$

3）画像検查所見：頭部・頸部 MRIにて明らかな異 常所見を認めず.

入院時現症：意識清明.

1）神経学的所見（右，左）

(i ）脳神経所見：異常なし。

（ii） MMT：腸腰筋・大腿四頭筋 $(3,3+)$, 前脛 骨筋 $(2 ， 2)$ ，両上肢は筋力低下なし。

(iii) 筋緊張 (modified Ashworth scale : MAS) : 膝 関節伸展 $(1+, 1+)$, 足関節背屈 $(1+, 1+)$, 両上肢は筋緊張なし。 
表 入院時・退院時の運動 FIM

\begin{tabular}{|c|c|c|}
\hline & 入院時 & 退院時 \\
\hline \multicolumn{3}{|l|}{ セルフケア } \\
\hline A. 食事 & 7 & 7 \\
\hline B．整容 & 5 & 7 \\
\hline C. 清拭 & 3 & 5 \\
\hline D．更衣（上半身） & 2 & 7 \\
\hline E．更衣（下半身） & 2 & 7 \\
\hline F．トイレ動作 & 5 & 6 \\
\hline \multicolumn{3}{|l|}{ 排泄コントロール } \\
\hline G. 排尿 & 1 & 7 \\
\hline H．排便 & 6 & 6 \\
\hline \multicolumn{3}{|l|}{ 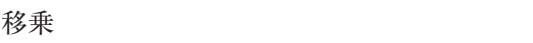 } \\
\hline I ．ベッド & 4 & 6 \\
\hline J 。トイレ & 4 & 6 \\
\hline K. 風呂, シャワー & 1 & 5 \\
\hline \multicolumn{3}{|l|}{ 移動 } \\
\hline L．歩行，車いす & 1 & 5 \\
\hline M. 階段 & 1 & 5 \\
\hline 合計 & 42 & 79 \\
\hline
\end{tabular}

（iv）深部腱反射：両下肢光進

（v）感覚検査：両下腿外側から足背にかけて痺れ を認めるが, 表在覚・深部覚の低下はなし. 両上肢には感覚障害なし。

2) 関節可動域：足関節背屈 $\left(0^{\circ}, 0^{\circ}\right)$

3）膀胱直腸障害：特になし

4）基本動作：ベッド柵を持って起き上がりは可能. 静的端座位は安定. 動的端座位, 立位保持は不 安定で見守りが必要.

5) 機能的自立度評価法 (Functional Independence Measure：FIM）：排尿, 移乗, 移動項目が大き く障害されていた (表).

併存疾患：アトピー性皮膚炎, 気管支喘息は幼少期 より認めていた。症状が増悪した時のみ近医を受診し ていた。成人してから症状が増悪したため, 内服薬や 吸入薬の治療を行っている.

生活歴・職歴: 高校卒業後, 短期大学で保育を専攻. 卒業後は障害者施設で指導員として勤務.

問題点と目標設定・治療方針：当院入院時は, 座 位・立位などの基本動作，更衣・移乗・移動の ADL 能力の低下を認めたため, 入院中は基本動作・ADL 向上を目標とした。歩行は短下肢装具を作成した上 で，実用的な移動手段として活用できるかを判断する こととした．また，できるだけ安全な生活様式を指導 し理解してもらうことを目標とした.
経過：初診時からの経過は図 2 に示す. 当院入院後, $\mathrm{X}+2$ 年 12 月は支持なしでの端座位, 立位保持が不安 定であったために座位・立位訓練など基本動作を中心 に訓練を行った. X+3 年 1 月には, 端座位は安定し た状態となったため, これまでの座位練習に加え，下 肢内転筋の緊張光進に対し, あぐら座位練習を行っ た.また歩行時に右足部の内反傾向が強いため，右金 属支柱付き短下肢装具（ダブルクレンザック継手）を 製作し，立位・歩行練習を行った。装具の継ぎ手に関 しては, 右足部離床をスムーズに行うために底屈 0 度 で制限することを試みたが, 完全に制限すると対側の 振り出し動作が行えないという状態となった。従っ て, 底屈 10 度の制限, 背屈は制限なしの設定とした ところ，右足部は少し引きずるようにはなるが，対側 の振り出し動作は可能な状態となった. 3 月に歩行補 助具は両側松葉杖とした (図 3). 同月より見守りで 病棟内歩行, 4 月には見守り屋外歩行訓練を行った. 屋内での動作に関して，両手の支持なく立位をとるこ とは危険であり，整容，調理などは基本的に車椅子座 位で行うように指導した。 入院経過中に 2 回程度下肢 筋緊張が充進することがあったが， 1 週間以内に元の 状態となった４月 28 日に家屋訪問を行い，5月 4 日 に自宅退院となった。退院後は B 大学病院神経内科, 市立病院呼吸器科・皮膚科, 当院でフォローすること とした。退院時の両足関節筋緊張（背屈）はMAS $(1+, 1+)$ の状態, ADL は全体的に動作レベルの向 上を認めた (表)。退院後は, 当院外来リハを継続, 短下肢装具の修正（摩耗した足尖部の取り換え，下肢 に圧迫を与える箇所へのクッション材取付等）を行っ た。また退院当初は, 自宅での生活において急に活動 量が増加して疲労することがみられたため, こまめに 休鄎を取ることや段階的に運動量を増やしていくなど の指導を行った。 6 月頃より右足関節筋緊張（背屈） はMAS $(1+\sim 2), 7$ 月初めには MAS $(2 \sim 3)$ と克 進傾向にあったため， 7 月 27 日に右下腿に A 型ボッ リヌス毒素製剤（ボトックス ${ }^{\circledR}$ ) (腓腹筋：計 100 単位, ヒラメ筋：100 単位, 後脛骨筋: 50 単位) を施行した。 施行後, 右足関節筋緊張（背屈）はMAS $(1+\sim 2)$ と軽度軽減したが，右股関節周囲筋，左下肢の筋緊張 は全体的に立進した. 他の運動機能, 感覚等の神経学 的所見の変化は認めなかった. 8 月には歩行時に左足 部も内反傾向となったため, 左金属支柱付き短下肢装 具の使用を検討した. その後バクロフェン（リオレ 
吉田直樹 · 他

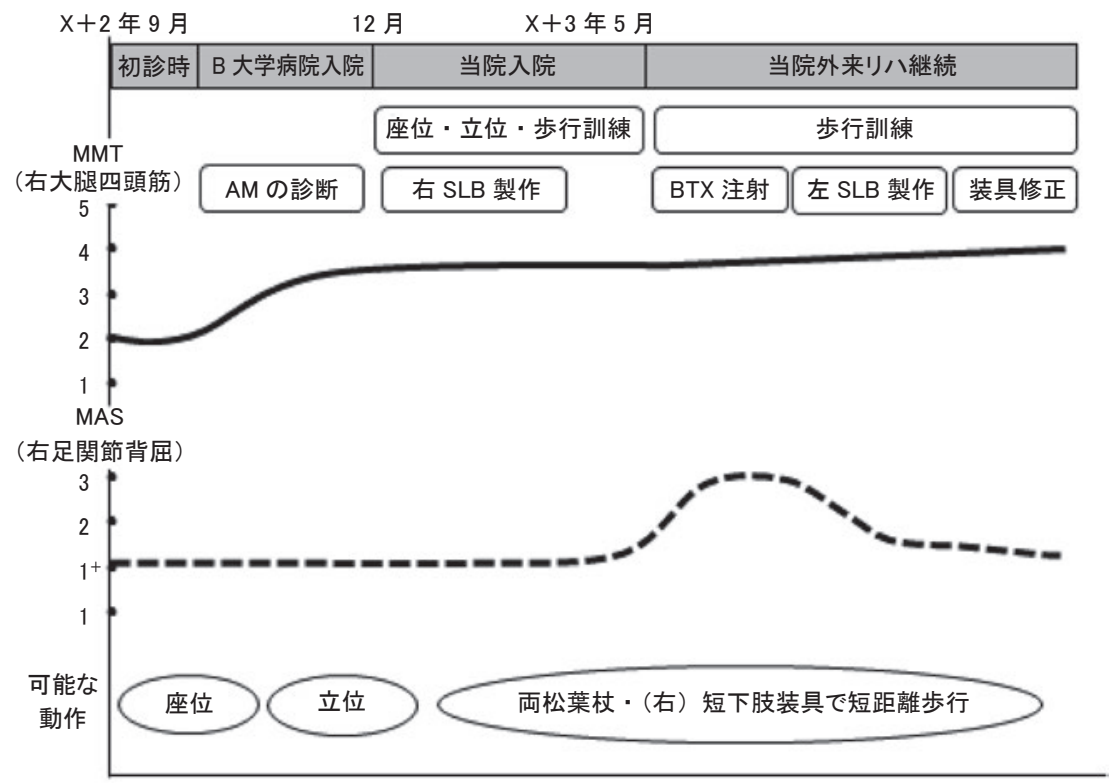

図 2 初診時からの経過

AM (atopic myelitis)：アトピー性脊髄炎, SLB (short leg brace) : 短下肢装具, BTX（Botulinum toxin）：ボッリヌス毒素, MMT（Manual Muscle Test）：徒手筋力テスト, MAS (modified Ashworth scale)

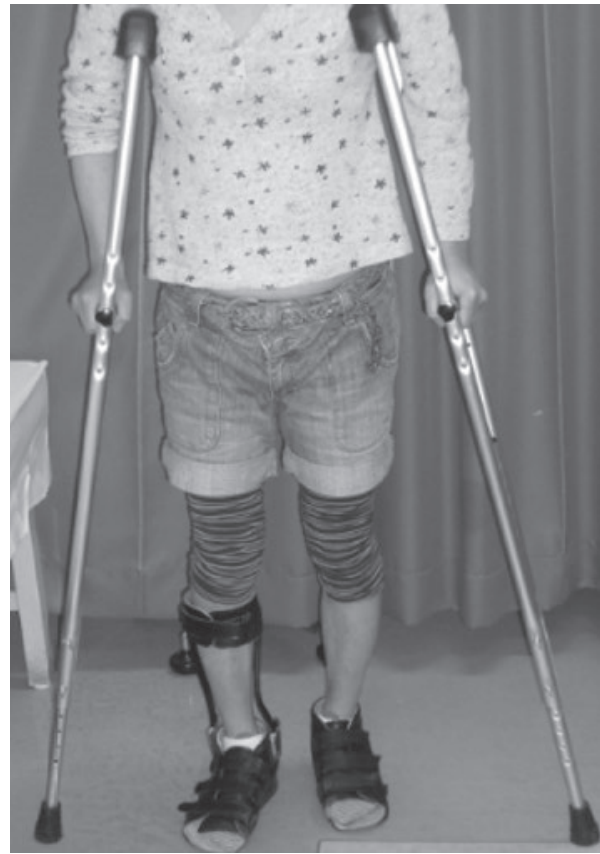

図 3 獲得した移動方法

両松葉杖，右金属支柱付短下肢装具で短距離歩 行移動が可能となった.
サール $\left.{ }^{\circledR}\right)$ の内服を開始し８月下旬には左足関節筋 緊張（背屈）はMAS $1+$ と軽減したが，今後も筋緊 張増減等の動摇性変化が起こりうる可能性を考慮し, 左金属支柱付き短下肢装具を製作し，筋緊張が増加し た場合は使用するように指導した。

\section{考察}

アトピー性脊髄炎（AM） は Kira らによって提唱さ れた疾患であり，(1)アトピー性皮膚炎が先行する，(2) 四肢遠位部の異常感覚を主徵とする，(3)臨床的に上部 頸髄病変の症状を高率に認める, (4) MRI では上部頸 髄背側に限局した病変が高率である，(5)高 $\operatorname{IgE}$ 抗体 血症をともなう，(6)ダ二特異的 $\operatorname{IgE}$ の上昇がみられ る，(7)髄液所見は正常である，8経過は軽い脊髄症候 が長く残存し MRI 上も小病変が長く残存する, と いった項目が本疾患の特徵として挙げられている ${ }^{4,8)}$. 治療は主に副腎皮質ステロイドのパルス療法で約 $2 / 3$ に改善がみられると報告されている。

2000 年に実施された全国調査（79 症例）では，平 均年齢 35 歳, 男女比 $1: 0.65$, 頸䯣病変の症状を $3 / 4$ に認めるが，その内 MRI で異常を認めるのは約 6 割 
であった．本症例でも MRIで異常所見を認めていな い。ただし初診時に両上肢に感覚障害を認めていたが 当院入院時には消失していた.これより少なくとも初 診時には頸髄に病変が存在していたと推察される。全 国調査によると本症例のような運動障害は $53.2 \%$, 反射立進は $73.4 \%$, 階段状進行もしくは動摇性の経 過を呈するのは 69.6\%であった ${ }^{10)}$. 観察期間は $67.3 \pm$ 47.5 力月だが, 多くは初期症状, 病理学的・免疫学的 特徵, 治療等についての報告で, 慢性経過のさらに具 体的な症状, 痤縮の変化・そのリハを含めた対応につ いてはほとんど記されていない.

今回リハでは，起き上がり・座位などの動作訓練， 短下肢装具の製作・調整，下肢痤縮への対応 - 生活様 式の指導等を中心に行った。体幹機能改善による座位 保持能力が向上して更衣動作，移乗動作が安定した. 装具装着下での歩行能力が安定して移動能力が向上し た.これらが回復期病院退院時の ADL 改善に大きく 影響したと考えられる。装具を用いての歩行調整に関 しては, 前足部離床が不良な場合は本来底屈を制限す る調整を行うが，今回は逆に対側の振り出し動作がで きなくなった。これは，装具によって底屈を制限する ことで伸筋共同運動パターンを利用した立脚後期の支 持動作が行えなくなり, それによって対側の振り出し 動作がスムーズに行えなくなったと考えらえる．結果 的に対側の振り出し動作を行うには，装具による足関 節底屈制限を解除せざるを得なかった．また，変動す る痤縮症状に対しては動摇性の症状変化と判断し, 抗 痤縮薬内服, ボッリヌス療法等で筋緊張軽減を図っ た。また痤縮状態に合わせて左下肢短下肢装具を装着 するように指導した。AM の長期的な経過は不明であ るが，動摇性症状に関してはパーキンソン病の日内変 動に対するその時の調子に合わせた対応 ${ }^{11)}$ や進行性 症状に対しては筋萎縮性側索硬化症の進行段階に応じ た対応 ${ }^{12)}$ のように，症状や状態に合わせた動作レべ ルの設定が必要とされる.

本症例よりリハ科として考えることは，急性期治療 後のリハ, 退院後のフォローも重要であるが, 初診時 の診察・対応を適切に行わなければならないというこ とである.今回，当院へは廃用症候群での外来リハ依 頼で受診した。廃用は，「症候群」として実に多くの 病態を網羅する概念である ${ }^{13)}$. Hirschbergの定義 ${ }^{14)}$ では，廃用症候群を「不活動状態により生ずる二次的 障害」としている。これまで廃用症候群の明確な診断
基準は開発されておらず，医師の臨床経験に基づいた 主観的判断に頼らざるを得なかった。本症例において も, 約 2 年間大学病院での神経内科も含め様々な精査 を行った上で当院紹介となったが，当院受診時，年 齢, 神経学的所見, 現病歴より単なる廃用症候群と考 え難く B 大学病院へ精査目的の紹介となった。それ が，結果的に 2 年間立つことができなかったが，両松 葉杖歩行までの改善に至った。佐鹿らは, 廃用障害 度, 廃用リスクスコア，廃用トリガー後要因，廃用徵 候などを評価し，分散分析，ROC（receiver operating characteristic）曲線，重回帰分析を行い，診断基準を 設定した ${ }^{15)}$. 本症例を再評価したが，廃用トリガーが 明確ではない，また廃用徵候点や廃用トリガー後要因 点が低いことから廃用症候群の診断基準を満たすもの ではなかった，今後は，このような廃用症候群の客観 的評価は大いに診断の参考になると考えられる。今 回，改めてリハ医としての初診への臨み方を考え直す と同時に，診断においてアトピー性脊髄炎のような稀 な疾患が存在することも考慮しつつ日々備えていく重 要性を認識した。振り返ると初診時, 明らかに顔面・ 四肢は湿疹様，一部色素沈着を呈していたが，神経症 状との関連を推察するに至らなかった。本症例の呈示 が，少しでも診療の場でお役に立つことがあれば幸い である。

\section{文 献}

1）古江増隆, 佐伯秀久, 古川福実, 秀道 広, 大槻マミ太郎, 片山一朗, 佐々木りか子, 須藤一, 竹原和彦 : アトピー 性皮膚炎ガイドライン. 日本皮膚科学会雑誌 $2009 ; 119$ : 1515-1534

2) 福井次矢 訳, 黒川 清 監修: ハリソン内科学 原著第 15 版.メディカル・サイエンス・インターナショナル, 東京, 2003

3）吉良潤一:アレルギー性疾患に伴う神経障害. 日本内科 学会雑誌 $2004 ; 93: 1017-1025$

4）吉良潤一: アトピー性脊䯣炎とその周辺. 炎症 $2000 ; 20$ : 137-144

5）吉良潤一, 越智博文, 小副川学：アトピー性脊髄炎と Hopkins症候群. 臨床神経 $2001 ; 41: 331$

6) Kira J, Yamasaki K, Kawano Y, Kobayashi T : Acute myelitis associated with hyperIgEemia and atopic dermatitis. J Neurol Sci 1997 ; 148 : 199-203

7) Horiuchi I, Kawano Y, Yamasaki K, Minohara M, Furue M, Taniwaki T, Miyazaki T, Kira J : Th 1 dominance in HAM/TSP and the optico-spinal form of multiple sclerosis versus Th 2 dominance in mite antigen-specific $\operatorname{IgE}$ myelitis. J Neurol Sci 2000 ; 172 : 17-24

8) Kira J, Kawano Y, Yamasaki K, Tobimatsu S : Acute my- 
elitis with hyperIgEemia and mite antigen specific IgE : atopic myelitis. J Neurol Neurosurg Psychiatry 1998 ; 64 : 676-679

9) Kira J, Kawano Y, Horiuchi I, Yamada T, Imayama S, Furue $\mathrm{M}$, Yamasaki $\mathrm{K}$ : Clinical, immunological and MRI features of myelitis with atopic dermatitis (atopic myelitis). J Neurol Sci 1999 ; $162: 56-61$

10) Osoegawa M, Ochi H, Minohara M, Murai H, Umehara F, Furuya H, Yamada T, Kira J : Myelitis with atopic diathesis : a nationwide survey of 79 cases in Japan. J Neurol Sci $2003 ; 209: 5-11$

11）大沼 剛, 阿部 勉, 戸津喜典 : パーキンソン病患者の リハビリテーションの実際とその具体的事例. 難病と
在宅ケア $2012 ; 16(9): 48-51$

12）杉村公也, 清水英樹 : 神経難病のリハビリテーション. 現代医学 $2005 ; 53(1): 113-118$

13）八幡徹太郎, 染矢富士子, 立野勝彦 : 臨床医にとっての 廃用症候群とは何か？一近年のリハビリテーション 診療から思うこと一. Jpn J Rehabil Med 2005 ; 42 : 696701

14) Hirschberg GG：リハビリテーション医学の実際（三好 正堂 訳), 改訂第 2 版. 日本アビリティーズ協会, 東京, 1980 ; pp 32-43

15）佐鹿博信, 水落和也, 菊地尚久, 若林秀隆 : 廃用症候群の 診断基準および障害度評価に関する試案. Jpn J Rehabil Med 2010; 47 (Suppl)：S 344 